\title{
Effect of Organic and Inorganic Sources of Nutrients on Yield Attributing Characteristics and Yield of Direct Seeded Rice in Inceptisols of Bastar Plateau Zone
}

\author{
Poornima Sahu*, T. Chandrakar, M. Paikra and K. K. Joshi
}

SG College of Agriculture \& Research Station, Jagdalpur (Chhattisgarh)-494005, India

*Corresponding author

\begin{tabular}{|c|c|}
\hline \multicolumn{2}{|r|}{ A B S T R A C T } \\
\hline & \multirow{5}{*}{$\begin{array}{l}\text { A field experiment was carried out at S.G. College of Agriculture and Research Station, } \\
\text { Jagdalpur, Chhattisgarh during Kharif } 2016 \text { to study the effect of organic and inorganic } \\
\text { sources of nutrients on soil chemical properties and nutrient availabilities under direct } \\
\text { seeded rice in Inceptisols of Bastar plateau zone. The experiment was conducted in } \\
\text { randomized block design with twelve treatments and four replications. The } 100 \% \text { NPK i.e. } \\
\text { recommended dose of fertilizers were } 100: 60: 40 \mathrm{~kg} \mathrm{~N}: \mathrm{P}_{2} \mathrm{O}_{5}: \mathrm{K}_{2} \mathrm{O} / \text { ha for rice crop. } \\
\text { Integrated nutrient management practice including } \mathrm{FYM} \text { and recommended dose of NPK } \\
\text { showed as best treatment with respect to growth and yield parameters like plant height, } \\
\text { panicle length no. of tillers and effective tillers, and test weight as compare to other } \\
\text { treatments. The grain ( } 46 \mathrm{q} / \mathrm{ha} \text { ) and straw ( } 51.3 \mathrm{q} / \text { ha) yield of rice was registered higher in } \\
\mathrm{T}_{8} \text { treatment followed by } \mathrm{T}_{7} \text { treatment ( } 44.8 \text { and } 50.2 \mathrm{q} / \mathrm{ha} \text { ) and lowest in control treatment } \\
(24.5 \text { and } 37.5 \mathrm{q} / \mathrm{ha}) \text {. Further the results suggest that inorganic fertilizer with organic } \\
\text { manure (FYM) enhanced the rice yield, soil fertility and soil physical and chemical } \\
\text { environment. }\end{array}$} \\
\hline & \\
\hline es, & \\
\hline Article Info & \\
\hline $\begin{array}{l}\text { Accepted: } \\
28 \text { February } \\
\text { Available } \\
10 \text { March } 2\end{array}$ & \\
\hline
\end{tabular}

\section{Introduction}

Rice (Oryza sativa L.) occupies a pride place among the food crops cultivated in India which has the largest area among rice growing countries and stands second in the production. A suitable combination of organic and inorganic source of nutrients is necessary for sustainable agriculture that can ensure food production with high quality. Thus, it is necessary to use fertilizer and manure in an integrated way in order to obtain sustainable crop yield without affecting soil fertility. Despite the past gains in rice production through chemical fertilizers, recent observations of stagnant or declining yields have raised concerns about the long-term sustainability of the crop production (Khan et al., 2010).

Continuous use of imbalanced fertilizers leads to deterioration in soil chemical, physical, biological properties and soil health (Mahajan et al., 2008). In India, area under cultivation of rice is around 43.38 mha with production of 104.32 million tonnes (Anon, 2016) while in the Chhattisgarh cover 3.70 mha area under rice cultivation and production is around 7.44 
$m$ tonnes (Anon, 2016). The soil organic matter plays an important role in improvement of soil physical, chemical and biological properties and ultimately increasing soil productivity and crop yields (Antil et al., 2011).

\section{Materials and Methods}

The field experiment was conducted in midland field under long term fertilizer experiment, AICRIP-Dryland Agriculture at SG College of Agriculture and Research Station, Kumhrawand, Jagdalpur (C.G.) during Kharif 2016.

The experiment was conducted with twelve treatments namely $\mathrm{T}_{1}$ (control), $\mathrm{T}_{2}(100 \% \mathrm{NPK}$ i.e. $\left.100: 60: 40 \mathrm{~kg} / \mathrm{ha} \mathrm{N}: \mathrm{P}_{2} \mathrm{O}_{5}: \mathrm{K}_{2} \mathrm{O}\right), \mathrm{T}_{3}(100 \%$ $\mathrm{PK}), \mathrm{T}_{4}(100 \% \mathrm{NK}), \mathrm{T}_{5}(100 \% \mathrm{NP}), \mathrm{T}_{6}(100 \%$ $\mathrm{NPK}+5$ t $\mathrm{FYM}), \mathrm{T}_{7}(100 \% \mathrm{NPK}+5$ t $\mathrm{FYM}+$ $\left.\mathrm{ZnSO}_{4} @ 25 \mathrm{~kg} \mathrm{ha}^{-1}\right), \mathrm{T}_{8}(100 \%$ NPK+5 t FYM+ $\mathrm{ZnSO}_{4} @ 25 \mathrm{~kg} \mathrm{ha}^{-1}+$ Lime $\left.3 \mathrm{q} \mathrm{ha}^{-1}\right), \mathrm{T}_{9}(50 \%$ NPK), $\mathrm{T}_{10}(50 \% \mathrm{NPK}+5 \mathrm{t}$ FYM $), \mathrm{T}_{11}(50 \%$ $\mathrm{NPK}+5 \mathrm{t}$ FYM+ ZnSO $@ 25 \mathrm{~kg} \mathrm{ha}^{-1}$ ) and $\mathrm{T}_{12}\left(50 \% \mathrm{NPK}+5 \mathrm{t} \mathrm{FYM}+\mathrm{ZnSO}_{4} @ 25 \mathrm{~kg} \mathrm{ha}^{-}\right.$ ${ }^{1}+$ Lime $3 \mathrm{q} \mathrm{ha}^{-1}$ ). The experiment was laid out in randomized block design (RBD) with four replications.

Ten plants were selected randomly 105 days after sowing (DAS) in each treatment and height was measured from ground surface using meter scale. The panicle length was recorded at maturity by taking observation of ten randomly selected plants from each plot.

Total and effective tillers of marked 10 hills of each treatment were recorded at the time of harvest. After this, average total and effective tillers were determined. Grain samples were taken from the produce of each net plot. Out of the samples, 1000 grains were counted and the same were air dried to constant weight. Thereafter, weight was recorded on electronic balance.

\section{Results and Discussion}

\section{Plant height}

Data presented on Table 1 indicated that there was significant effect of different treatments on height of rice crop. Application of $100 \%$ $\mathrm{NPK}+5 \mathrm{t} \mathrm{FYM}+\mathrm{ZnSO}_{4} @ 25 \mathrm{~kg} / \mathrm{ha}\left(\mathrm{T}_{7}\right)$ recorded the highest plant height $(94.5 \mathrm{~cm})$ at 105 DAS of rice which was at par with $100 \%$ NPK $\left(\mathrm{T}_{2}\right)$ but significantly superior to control $(81 \mathrm{~cm})$. There were 16.67 and 12.22 per cent increase in plant height in $\mathrm{T}_{7}$ and $\mathrm{T}_{2}$, respectively over control. The combined use of organic and inorganic sources of plant nutrients in varying proportions resulted better growth of the plants compare to inorganics alone. The half doses of RDF combined with FYM alone or with combination of lime and zinc sulphate resulted in significant increase in plant height as compare to control and remained at par with full doses of RDF.

\section{Number of tillers and effective tillers}

Data showed that the different treatments of fertilizers and manures showed significant variations in respect of number of tillers and effective tillers per hill (Table.1). Among the different treatments, 100\% NPK +5 t FYM + $\mathrm{ZnSO}_{4} @ 25 \mathrm{~kg} / \mathrm{ha}+$ lime 3 q/ha $\left(\mathrm{T}_{8}\right)$ significantly enhanced the number of tillers (6.9) and effective tillers per hill (6.2) over control (5 \& 4.3) which was at par with $100 \%$ $\mathrm{NPK}+5$ t FYM + $\mathrm{ZnSO}_{4} @ 25 \mathrm{~kg} / \mathrm{ha}\left(\mathrm{T}_{7}\right)$ and $50 \% \mathrm{NPK}+5 \mathrm{t} \mathrm{FYM}+\mathrm{ZnSO}_{4} @ 25 \mathrm{~kg} / \mathrm{ha}$ + lime $3 \mathrm{q} / \mathrm{ha}\left(\mathrm{T}_{12}\right)$. The half doses of RDF combined with FYM alone or with combination of lime and zinc sulphate resulted in significant increase in number of tillers and effective tillers per hill as compare to control and remained at par with full doses of RDF. Nayak et al., (2007) reported a significant increase in number of effective tillers per hill due to application of chemical fertilizer with organic manure. 
Table.1 Effect of organic and inorganic sources of nutrients on rice yield attributing characters

\begin{tabular}{|c|c|c|c|c|c|}
\hline Treatment & $\begin{array}{c}\text { Plant } \\
\text { height }(\mathrm{cm})\end{array}$ & $\begin{array}{l}\text { No. of tiller } \\
\text { / Plant }\end{array}$ & $\begin{array}{l}\text { No. of } \\
\text { effective tiller }\end{array}$ & $\begin{array}{l}\text { Panicle } \\
\text { length } \\
(\mathrm{cm})\end{array}$ & $\begin{array}{c}1000 \\
\text { grain wt. } \\
(\mathrm{gm})\end{array}$ \\
\hline Control & 81.0 & 5.0 & 4.3 & 20.0 & 23.4 \\
\hline $100 \%$ NPK & 90.9 & 5.6 & 5.1 & 21.7 & 27.1 \\
\hline $100 \%$ PK & 81.8 & 5.0 & 4.7 & 20.4 & 26.1 \\
\hline $100 \%$ NK & 90.4 & 5.5 & 5.0 & 21.2 & 26.2 \\
\hline $100 \% \mathrm{NP}$ & 89.7 & 4.7 & 4.5 & 21.6 & 26.1 \\
\hline $100 \%$ NPK + 5 t FYM & 92.2 & 5.7 & 5.3 & 22.3 & 27.7 \\
\hline $\begin{array}{l}\text { 100\% NPK+5 t FYM+ } \\
\mathrm{ZnSO}_{4} @ 25 \mathrm{~kg} \mathrm{ha}^{-1}\end{array}$ & 94.5 & 6.4 & 6.1 & 22.3 & 26.1 \\
\hline $\begin{array}{l}100 \% \text { NPK+5 t FYM+ } \\
\mathrm{ZnSO}_{4} @ 25 \mathrm{~kg} \mathrm{ha}^{-1}+\text { Lime } 3 \mathrm{q} \mathrm{ha}^{-1}\end{array}$ & 93.9 & 6.9 & 6.2 & 22.4 & 27.2 \\
\hline $50 \%$ NPK & 87.5 & 5.5 & 5.0 & 21.3 & 25.0 \\
\hline $50 \%$ NPK + 5 t FYM & 90.8 & 5.8 & 5.2 & 21.9 & 26.2 \\
\hline $\begin{array}{l}50 \% \text { NPK + } 5 \text { t FYM+ }^{-1} \\
\mathrm{ZnSO}_{4} @ 25 \mathrm{~kg} \mathrm{ha}^{-1}\end{array}$ & 89.2 & 5.3 & 4.8 & 21.9 & 26.1 \\
\hline $\begin{array}{l}50 \% \text { NPK + } 5 \text { t FYM+ } \\
\mathrm{ZnSO}_{4} @ 25 \mathrm{~kg} \mathrm{ha}^{-1}+\text { Lime } 3 \mathrm{q} \mathrm{ha}^{-1} \\
\end{array}$ & 88.7 & 6.2 & 6.0 & 22.3 & 26.7 \\
\hline CV \% & 3.1 & 23.6 & 19.4 & 3.1 & 4.1 \\
\hline CD (5\%) & 4.0 & 1.7 & 1.3 & 0.9 & 1.5 \\
\hline CD (1\%) & 5.3 & 2.3 & 1.8 & 1.3 & 2.0 \\
\hline
\end{tabular}

Table.2 Effect of Treatments on yield of rice (MTU 1010)

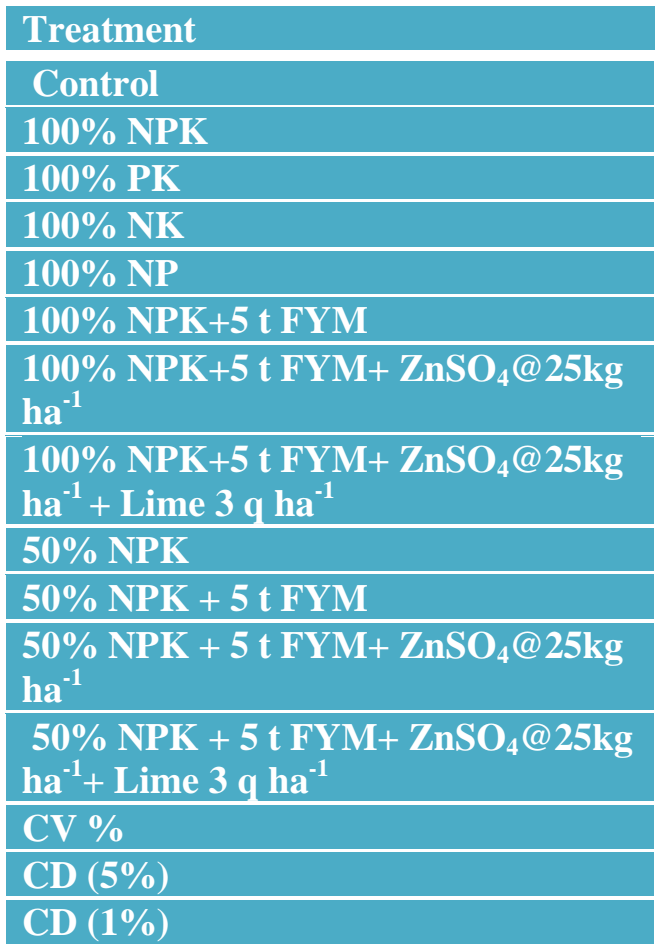

\begin{tabular}{|c|c|c|}
\hline Grain yield (q/ha) & Straw yield (q/ha) & Harvest index \\
\hline 24.5 & 37.5 & 39.5 \\
\hline 39.8 & 48.5 & 45.0 \\
\hline 27.4 & 38.7 & 41.5 \\
\hline 32.1 & 37.7 & 46.0 \\
\hline 35.5 & 41.5 & 46.1 \\
\hline 41.8 & 49.7 & 45.6 \\
\hline 44.8 & 50.2 & 47.2 \\
\hline 46.0 & 51.3 & 47.2 \\
\hline 35.0 & 43.5 & 44.4 \\
\hline 36.6 & 43.2 & 45.8 \\
\hline 38.5 & 43.9 & 46.7 \\
\hline 38.9 & 46.0 & 45.8 \\
\hline 7.9 & 4.6 & 5.02 \\
\hline 4.1 & 2.9 & 3.2 \\
\hline 5.6 & 3.9 & 4.3 \\
\hline
\end{tabular}




\section{Panicle length}

Different treatments of fertilizer and manure showed significant variations in respect of panicle length. Table 1 showed the maximum panicle length $(22.4 \mathrm{~cm})$ and were noted in $100 \% \mathrm{NPK}+5 \mathrm{t} \mathrm{FYM}+\mathrm{ZnSO}_{4} @ 25 \mathrm{~kg} / \mathrm{ha}+$ lime $3 \mathrm{q} / \mathrm{ha} \quad\left(\mathrm{T}_{8}\right)$ which was found significantly higher than control $(20 \mathrm{~cm})$ but remained at par with $50 \% \mathrm{NPK}+5 \mathrm{t} \mathrm{FYM}+$ $\mathrm{ZnSO}_{4} @ 25 \mathrm{~kg} / \mathrm{ha}+$ lime $3 \mathrm{q} / \mathrm{ha}\left(\mathrm{T}_{12}\right), 100 \%$ $\mathrm{NPK}+5 \mathrm{t} \mathrm{FYM}+\mathrm{ZnSO}_{4} @ 25 \mathrm{~kg} / \mathrm{ha}\left(\mathrm{T}_{7}\right)$ and $100 \% \mathrm{NPK}+5$ t FYM $\left(\mathrm{T}_{6}\right)$ which have $22.2 \mathrm{~cm}$ panicle length. The combine use of organic and inorganic fertilizer increases panicle length as compare to inorganics alone but were at par. Similar, resulted was also found by Islam et al., (2010).

\section{Test Weight}

The data on test weight (1000- seeds) is presented in Table 4.2. The highest test weight, $27.7 \mathrm{~g}$ was recorded in $100 \% \mathrm{NPK}+5$ t FYM ( $\left.\mathrm{T}_{6}\right)$ followed by $27.2 \mathrm{~g}$ in $100 \% \mathrm{NPK}$ +5 t FYM + $\mathrm{ZnSO}_{4} @ 25 \mathrm{~kg} / \mathrm{ha}+$ lime $3 \mathrm{q} / \mathrm{ha}$ $\left(\mathrm{T}_{8}\right)$ and lowest $(23.4 \mathrm{~g})$ in control plot. Yang et al., (2004) recorded that 1000-grain weight was increased by the application of chemical fertilizer along with organic manure.

\section{Grain yield}

Grain yield of rice increased significantly with different level of organic and inorganic fertilizers (Table.2). Grain yield of rice varied from 24.5 to $46.0 \mathrm{q} /$ ha amongst different nutrient concentration alone and along with organics. The maximum grain (46 q/ ha) were obtained with $100 \%$ NPK+ 5 t $\mathrm{FYM}+$ $\mathrm{ZnSO}_{4} @ 25 \mathrm{~kg} / \mathrm{ha}+$ lime 3q/ ha $\left(\mathrm{T}_{8}\right)$. This may be due to the higher available nutrients and optimum soil properties in the plots receiving higher dose $(100 \% \mathrm{NPK}+5 \mathrm{t} \mathrm{FYM}+$ $\mathrm{ZnSO}_{4} @ 25 \mathrm{~kg} / \mathrm{ha}+$ lime 3q/ ha) of inorganic and organic fertilizers. The integrated effects of fertilizer and farm yard manure were noted to be more beneficial than the use of chemical fertilizer alone. Additional increase in grain yield was registered due to the integrated effect of FYM with inorganic fertilizer. The half doses of RDF combined with FYM alone or with combination of lime and zinc sulphate resulted in significant increase in grain yield as compare to control and remained at par with full doses of RDF. Similar findings were reported by Ghosh and Singh (2003), Chaudary and Thakur (2007) and Urkurkar et al., (2010).

\section{Straw yield}

Data presented on Table 2 indicated that there was significant effect of different treatments on straw yield of rice crop. It ranges from 37.5 to $51.3 \mathrm{q} \mathrm{ha}^{-1}$. The higher straw yield $\left(51.3 \mathrm{q} \mathrm{ha}^{-1}\right)$ was recorded in T8 $(100 \%$ $\mathrm{NPK}+5 \mathrm{t}$ FYM+ ZnSO $@$ @25kg/ha+ lime 3q/ ha) while the minimum straw yield ( $37.5 \mathrm{q}$ ha ${ }^{-1}$ ) was recorded in $\mathrm{T} 1$ (control). The treatment $\mathrm{T} 8$ was found statistically at par with T6 (100\% NPK+ 5 t FYM) and T7 (100\% NPK+ 5 t FYM+ ZnSO $@ 25 \mathrm{~kg} / \mathrm{ha})$ but it was superior to rest of the treatments. Application of RDF with FYM, zinc sulphate and lime improved straw yields which might be due to favorable soil condition. Alim (2012) and Urkurkar et al., (2010) reported similar findings.

\section{References}

Alim, M. A. 2012. Effect of organic and inorganic sources and doses of nitrogen Fertilizer on the yield of Boro rice. J. Environ. Sci. \& Natural Res. 5(1): 273282.

Anonymous 2017. Annual report 2016-17. Department of Agriculture Cooperation \& farmers welfare ministry of Agriculture \& Government of India Krishi Bhavan. New Delhi 110-001:3-7. 
Anonymous 2017. Krishi Darshika IGKV (C.G.): 4-5.

Antil, R.S., Narwal, R.P., Singh, B and Singh, J.P. 2011. Long- term effects of FYM and $\mathrm{N}$ on soil health and crop productivity under pearl millet - wheat cropping system. Ind.J.Fert. 7:14-32.

Chaudhary, S.K. and Thakur, R.B. 2007. Efficient farm yard management for sustained productivity of rice (Oryza sativa) - wheat (Triticum aestivum) cropping system. Indian J. Agril. Sci. 77(7): 443-444.

Ghosh, B.N. and Singh, R.D. 2003. Effect of conjoint use of farmyard manure and nitrogen on rice (Oryza sativa) - Wheat (Triticum aestivum) system in Uttaranchal mid-hill soils. Indian $\mathrm{J}$. Agril. Sci. 73 (12): 680-683.

Islam, M. S., Islam M. Z., Rahman, G. K. M. M. and Chowdhury M. A. A. H. 2010. Effect of Some Secondary and Micro Nutrients Along With Organic Amendments on T. Aman. Int. J. Sustain. Crop Prod. 5(4):51-58.

Khan, N.I., Malik, A.U., Umer, F and Bodla, M.I. 2010. Effect of Tillage and Farm
Yard Manure on physical properties of soil. Int. Res. J. of plant sci. 1(4):75-82.

Mahajan, A., Bhagat, R.M. and Gupta R.D. 2008. Integrated Nutrient Management in sustainable Rice-Wheat cropping system for Food security in India. SAARC J. Agri. 6(2): 29-32.

Nayak, D. R., Babu, X., and Adhya, T. K. 2007. Long-term application of compost influences mineral biomass and enzyme activities in a tropical Aeric Endoaquept planted to rice under flooded condition. Soil Bio. \& Biochem. 39(8):1897-1906.

Urkurkar, J.S., Tiwari, A., Shrikanth Chitale and Bajpai, R.K. 2010. Influence of long term use of inorganic and organic manures on soil fertility and sustainable productivity of rice (Oryza sativa) and Wheat (Triticum aestivum) in Inceptisols. Indian J. of Agril. Sci. 80. (3): 208-212.

Yang, C. M., Yang, L., Yang, Y., Ouyang, Z. 2004. Rice root growth and nutrient uptake as influenced by organic manure in continuously and alternately flooded paddy soils. Agril. Water Mgt. 70(1):67-81.

\section{How to cite this article:}

Poornima Sahu, T. Chandrakar, M. Paikra and Joshi K. K. 2018. Effect of Organic and Inorganic Sources of Nutrients on Yield Attributing Characteristics and Yield of Direct Seeded Rice in Inceptisols of Bastar Plateau Zone. Int.J.Curr.Microbiol.App.Sci. 7(03): 3757-3761. doi: https://doi.org/10.20546/ijcmas.2018.703.434 